\title{
Chronic effects of nitrogenous compounds on survival and growth of juvenile pink shrimp
}

\author{
W. J. Wasielesky ${ }^{a}$, L. H. Poersch ${ }^{a}$, T. G. Martins ${ }^{a}$ and K. C. Miranda-Filho ${ }^{b *}$ \\ ${ }^{a}$ Laboratório de Carcinocultura Marinha, Instituto de Oceanografia, Universidade Federal do Rio Grande - FURG, \\ Cassino, CEP 96201-900, Rio Grande, RS, Brazil \\ ${ }^{\mathrm{b}}$ Laboratório de Aquacultura, Departamento de Zootecnia, Escola de Veterinária, Universidade Federal de Minas Gerais - \\ UFMG, Avenida Antônio Carlos, 6627, CEP 31270-901, Belo Horizonte, MG, Brazil \\ *e-mail: kmiranda2010@ufmg.br, kleber08@gmail.com
}

Received: November 12, 2015 - Accepted: April 22, 2016 - Distributed: August 31, 2017

\begin{abstract}
In response to growing worldwide market demand, intensive shrimp farming, based on high feed, has developed over the past decade. The nitrogenous compounds mainly generated by animal excretion can cause deterioration of water quality and produce chronic or even acute toxicity to aquatic animals. As prevention, theoretical safety levels have been estimated from acute toxicity tests and they are traditionally used to prevent toxic effects on biota. However, are those concentrations of nitrogenous compounds really safe to Farfantepenaeus paulensis? The current study aimed to investigate the lethal and sublethal effects of ammonia, nitrite and nitrate to juvenile $F$. paulensis based on safety levels. Each experiment was performed independently in $100 \mathrm{~L}$ tanks for 30 days. The survival rates and wet weight of all shrimps were recorded every 10 days. The concentrations tested for ammonia, nitrite and nitrate were respectively: treatment " $\mathrm{T}_{1 / 4}$ ", a quarter of the safety level $\left(0.91 \mathrm{mg} / \mathrm{L} \mathrm{TA}-\mathrm{N}, 2.55 \mathrm{mg} / \mathrm{L} \mathrm{NO}_{2}^{-}-\mathrm{N}\right.$ and $\left.80.7 \mathrm{mg} / \mathrm{L} \mathrm{NO}_{3}^{-}-\mathrm{N}\right)$; treatment " $\mathrm{T}_{\mathrm{SL}}$ ", the safety level (3.65 mg/L TA-N, $10.2 \mathrm{mg} / \mathrm{L} \mathrm{NO}_{2}{ }^{-} \mathrm{N}$ and $\left.323 \mathrm{mg} / \mathrm{L} \mathrm{NO}_{3}{ }^{-} \mathrm{N}\right)$; and treatment " $\mathrm{T}_{2 \mathrm{X}}$ ", twice the safety level $\left(7.30 \mathrm{mg} / \mathrm{L}\right.$ TA-N, $20.4 \mathrm{mg} / \mathrm{L} \mathrm{NO}_{2}^{-}-\mathrm{N}$ and $\left.646 \mathrm{mg} / \mathrm{L} \mathrm{NO}_{3}^{-}-\mathrm{N}\right)$. For F. paulensis cultivation, the real safety level for nitrite was estimated to be $2.55 \mathrm{mg} / \mathrm{L} \mathrm{NO} \mathrm{N}_{2}^{-}-\mathrm{N}$. For ammonia and nitrate, the recommended concentrations were $<0.91 \mathrm{mg} / \mathrm{L}$ TA-N corresponding to $0.045 \mathrm{mg} / \mathrm{L} \mathrm{NH}_{3}-\mathrm{N}$ and $<80.7 \mathrm{mg} / \mathrm{L} \mathrm{NO}_{3}^{-}-\mathrm{N}$, respectively.
\end{abstract}

Keywords: ammonia, aquaculture, nitrate, nitrite, water quality.

\section{Efeito crônico de compostos nitrogenados sobre a sobrevivência e crescimento de juvenis de camarão rosa}

\section{Resumo}

Em resposta à crescente demanda do mercado mundial, a carcinicultura intensiva tem se desenvolvido ao longo da última década. Os compostos nitrogenados gerados principalmente pela excreção dos animais podem causar a deterioração da qualidade da água e produzir toxicidade crônica ou mesmo aguda para os animais cultivados. Como prevenção, os níveis de segurança teóricos são estimados a partir de testes de toxicidade aguda e são tradicionalmente usados para evitar efeitos tóxicos sobre a biota. No entanto, as estimativas das concentrações dos compostos nitrogenados são realmente seguras para Farfantepenaeus paulensis? O presente estudo teve como objetivo investigar os efeitos letais e subletais da amônia, nitrito e nitrato em juvenis de camarão marinho $F$. paulensis com base em níveis de segurança. Cada experimento foi realizado de forma independente em tanques com capacidade de $100 \mathrm{~L}$ durante 30 dias. As taxas de sobrevivência e peso úmido de todos os camarões foram registrados a cada 10 dias. As concentrações testadas para amônia, nitrito e nitrato foram respectivamente: " $\mathrm{T}_{1 / 4}$ ", um quarto do nível de segurança $(0,91 \mathrm{mg} / \mathrm{L} \mathrm{N}-\mathrm{AT}$, $2,55 \mathrm{mg} / \mathrm{L}$ de $\mathrm{N}_{-\mathrm{NO}_{2}}^{-}$e $\left.80,7 \mathrm{mg} / \mathrm{L} \mathrm{N}-\mathrm{NO}_{3}{ }^{-}\right)$; " $\mathrm{T}_{\mathrm{SL}}$ ", nível de segurança $\left(3,65 \mathrm{mg} / \mathrm{L} \mathrm{N}-\mathrm{AT}, 10,2 \mathrm{mg} / \mathrm{L}\right.$ de $\mathrm{N}-\mathrm{NO}_{2}{ }^{-} \mathrm{e}$

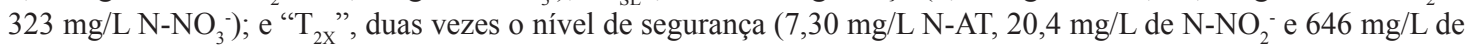
$\mathrm{N}^{-} \mathrm{NO}_{3}^{-}$). Para a criação de F. paulensis, o nível de segurança real para nitrito foi estimado em $2,55 \mathrm{mg} / \mathrm{L} \mathrm{N}-\mathrm{NO}_{2}{ }^{-}$. Para amônia e nitrato, concentrações recomendadas foram: $<0,91 \mathrm{mg} / \mathrm{L} \mathrm{N}$-AT correspondente a $0,045 \mathrm{mg} / \mathrm{L} \mathrm{N}_{-} \mathrm{NH}_{3}$ e $<80,7 \mathrm{mg} / \mathrm{L} \mathrm{N}^{-N_{3}}{ }_{3}^{-}$, respectivamente.

Palavras-chave: amônia, aquicultura, nitrato, nitrito, qualidade da água. 


\section{Introduction}

The pink shrimp Farfantepenaeus paulensis (Latreille, 1817 ) is a euryhaline crustacean and commercially important in Brazil. Many studies have been performed in order to introduce it in aquaculture (Abreu et al., 2007; Ballester et al., 2007, 2010; Emerenciano et al., 2007; Henriques et al., 2014; Peixoto et al., 2003, 2004; Tsuzuki and Cavalli, 2000; Wasielesky et al., 2003).

Nowadays, the development of aquaculture techniques resulted in intensification of culture conditions. The feed used in aquaculture systems contain high levels of crude protein. Therefore, the release of nitrogen to the environment has increased. The main sources of these substances are: excretion of cultured organisms and organic matter mineralization (Baldisserotto, 2009; Lazzari and Baldisserotto, 2008; Tomasso, 1994).

Ammonia is the final product of protein catabolism in most aquatic organisms. It occurs naturally in aquatic systems and in aqueous solution in two different chemical forms. The medium becomes more or less toxic based on the concentration of unionized or gaseous ammonia $\left(\mathrm{NH}_{3}\right)$ (Wright and Wood, 2012).

Nitrite is the intermediate compound in the bacterial nitrification of ammonia to nitrate in oxidizing environments and the product of the denitrification of nitrate in reducing environments (Thurston et al., 1978). The accumulation of nitrite may degrade water quality, increasing both the consumption of oxygen and excretion of ammonia, reducing animal growth and even mortality (Lin and Chen, 2003). The nitrite binds to hemocyanin, occupying the active site in place of oxygen and causing a transformation to meta-hemocyanin, which is unable to transfer oxygen to the tissues. For this reason, nitrite decreases the amount of oxygen available for tissue oxygenation (Tahon et al., 1988). As a result, hypoxia and hypoxia-related mortality may occur (Chen and Chin, 1988; Chen et al., 1986). Nitrite can also inhibit carbonic anhydrase, a metallo-enzyme that influences branchial ion transport in freshwater fish and crustaceans (Innocenti et al., 2004).

In turn, researchers and farmers view nitrate as a weakly toxic substance. As the product of nitrification, this compound can accumulate in large quantities, especially in closed aquaculture systems (Spieck and Bock, 2005; Thurston et al., 1978) such as Recirculating Aquaculture System (RAS) (Kuhn et al., 2010) and Biofloc Technology (BFT) (Luo et al., 2013). Thus, this substance can cause lethal (Tsai and Chen, 2002) or sublethal (Kuhn et al., 2010) effects to aquatic organisms or act synergistically with other nitrogenous compounds.

The deleterious effects of nitrogenous compounds have been analyzed in penaeid shrimp (Barbieri, 2010; Kir and Kumlu, 2006; Lin and Chen, 2001; Romano and Zeng, 2013). Independent studies were carried out with $F$. paulensis as follows: Ostrensky et al. (1992) examined the toxicity of ammonia in the production of post-larvae; Ostrensky and Wasielesky (1995) have estimated the $\mathrm{LC}_{50}(24-96 \mathrm{~h})$ of ammonia in different stages of $F$. paulensis; Cavalli et al.
(1996) determined the $\mathrm{LC}_{50}(96 \mathrm{~h})$ of nitrogenous products for pink shrimp adults; and Peixoto (1996) determined the effects of ammonia on the number of spawning events, the fecundity and the hatching rate. In addition, Miranda-Filho et al. (2009) examined the toxic effects of ammonia on the growth of the early stages of $F$. paulensis (nursery phase); Ostrensky (1997) determined the lethal effects of mixtures of ammonia and nitrite; and Castaño (1997) and Sachisida (1997) analyzed the effect of salinity on the acute toxicity of nitrite and nitrate, respectively. From the acute toxicity tests performed with nitrogenous compounds, it is possible to estimate the species-specific safety levels in order to predict toxicity thresholds, as described by Sprague (1971).

Despite these studies, according to Romano and Zeng (2013), theoretical safety levels can underestimate the impact of nitrogenous waste on the growth and physiological condition of crustaceans. So, are the safety concentrations of nitrogenous compounds estimated to $F$. paulensis really safe?

For these reasons, the present research was carried out in order to study the estimated safety levels for nitrogenous compounds (ammonia, nitrite and nitrate) on the survival and growth of juvenile $F$. paulensis and also define real safety levels for commercial pink-shrimp production.

\section{Materials and Methods}

Juvenile shrimps (170 $\pm 45 \mathrm{mg})$, obtained from local laboratory reproduction, were acclimated for 15 days under the conditions to be used in the toxicity tests. The tests were performed independently and based on the same methodology. Each toxicity test was performed in 100-L tanks of experimental medium with a $12 \mathrm{~h}$ photoperiod, constant aeration, temperature $25^{\circ} \mathrm{C}$ and salinity $15 \mathrm{ppt}$ (obtained from seawater pumped and adjusted with municipal freshwater free of chlorine). Three replicates were used per treatment $(n=30)$.

Safety levels were used to establish the chronic concentrations for the three nitrogenous compounds. They were based on the application factor proposed by Sprague (1971), which corresponded $10 \%$ of the $\mathrm{LC}_{50}$ $(96 \mathrm{~h})$ and were estimated as follows: ammonia $=3.87$ $\mathrm{mg} / \mathrm{L} \mathrm{TA}-\mathrm{N}$ based on the work of Ostrensky and Wasielesky (1995), nitrite $=10.2 \mathrm{mg} / \mathrm{L} \mathrm{NO}_{2}{ }^{-}-\mathrm{N}$ based on the work of Castaño (1997) and nitrate $=323 \mathrm{mg} / \mathrm{L} \mathrm{NO}_{3}-\mathrm{N}$ based on the work of Sachisida (1997). According to these data, the concentrations used in the experiments for ammonia, nitrite and nitrate were respectively: treatment $\mathrm{T}_{1 / 4}$, a quarter of the safety level $\left(0.91 \mathrm{mg} / \mathrm{L}\right.$ TA-N, $2.55 \mathrm{mg} / \mathrm{L} \mathrm{NO}_{2}{ }^{-}-\mathrm{N}$ and $\left.80.7 \mathrm{mg} / \mathrm{L} \mathrm{NO}_{3}^{-}-\mathrm{N}\right)$; treatment $\mathrm{T}_{\mathrm{SL}}$, the safety level (3.65 mg/L TA-N, $10.2 \mathrm{mg} / \mathrm{L} \mathrm{NO}_{2}{ }^{-}-\mathrm{N}$ and $\left.323 \mathrm{mg} / \mathrm{L} \mathrm{NO}_{3}{ }^{-} \mathrm{N}\right)$; and treatment $\mathrm{T}_{2 \mathrm{X}}$, twice the safety level $(7.30 \mathrm{mg} / \mathrm{L} \mathrm{TA}-\mathrm{N}$, $20.4 \mathrm{mg} / \mathrm{L} \mathrm{NO}_{2}^{-}-\mathrm{N}$ and $646 \mathrm{mg} / \mathrm{L} \mathrm{NO}_{2}^{-}-\mathrm{N}$ ).

The reagents used for the preparation of experimental media for chronic tests were as follow: ammonium chloride $\left(\mathrm{NH}_{4} \mathrm{Cl}\right)$ (Synth), sodium nitrite $\left(\mathrm{NaNO}_{2}\right)$ (Synth) and sodium nitrate $\left(\mathrm{NaNO}_{3}\right)$ (Synth). The tests were performed 
in triplicate. In each replicate, 30 juvenile shrimps ( 90 per treatment) were fed daily with MR35 (Nestlé-Purina ${ }^{\circledR}$, Brazil) and fresh food (fish and crab) until apparent satiation. The salinity, temperature and $\mathrm{pH}$ in all solutions were recorded daily. These variables were monitored and used to determine the proportions of ionized $\left(\mathrm{NH}_{4}^{+}\right)$and un-ionized ammonia $\left(\mathrm{NH}_{3}\right)$ in the experimental media. These proportions were calculated from the concentrations of total ammonia used in the various treatments based on the equations in Whitfield (1974) and Bower and Bidwell (1978) as adapted by Ostrensky et al. (1992).

Eighty percent daily renewals were performed to maintain the physicochemical properties of the water. The total duration of the test was 30 days. At the $15^{\text {th }}$ day of experimental period, shrimps were transferred to clean tanks to prevent the attachment of nitrifying bacteria (e.g. Nitrobacter and Nitrosomonas) that would cause significant variation in the concentrations of nitrogenous compounds due to the nitrification process.

Every 10 days during the chronic test, the survival rates and wet weight of all shrimp tested were recorded. The data on survival, wet weight and final biomass were subjected to an analysis of variance (ANOVA). The data analysis was conducted in view of the assumptions of this method. The Tukey test was applied if the toxic effects observed showed significant differences $(\mathrm{P}<0.05)$.

\section{Results}

The mean concentrations of ammonia, nitrite and nitrate and the physicochemical variables data were recorded (Table 1).
The survival of $F$. paulensis exposed to ammonia was the lowest $(\mathrm{P}<0.05)$ in $\mathrm{T}_{2 \mathrm{X}}$. Based on the results of survival and final weight, the total biomass data were calculated for each treatment and showed a significant decrease with increasing level of exposure to ammonia (Table 2).

Regarding nitrite, survival rates of $F$. paulensis varied between $15.7 \%$ and $91.0 \%$. Control and $\mathrm{T}_{1 / 4}$ survival was significantly higher $(\mathrm{P}<0.05)$ than $\mathrm{T}_{\mathrm{SL}}$ and $\mathrm{T}_{2 \mathrm{X}}$ (Table 3$)$. Only shrimps exposed to $T_{2 X}$ had lower growth $(P<0.05)$ compared to other treatments tested. Final biomass ranged from $1.46 \mathrm{~g}$ to $11.49 \mathrm{~g}$, and was significantly lower in groups exposed to $\mathrm{T}_{\mathrm{SL}}$ and $\mathrm{T}_{2 \mathrm{X}}$ (Table 3 ).

According to nitrate toxicity test, the lowest $(\mathrm{P}<0.05)$ survival rate $(40.0 \%)$ was observed in the $\mathrm{T}_{2 \mathrm{x}}$. Other survival rates varied between 70.2 and $88.9 \%$, showing no significant differences $(\mathrm{P}>0.05)$. The final biomass of F. paulensis significantly decreased with increasing nitrate concentrations (Table 4), presenting chronic effects on F. paulensis (Table 4).

\section{Discussion}

Recently, several authors have conducted studies to determine the acute toxicity of various nitrogenous compounds to aquatic cultured organisms (Barbieri, 2010; Romano and Zeng, 2013). The median lethal concentrations $\left(\mathrm{LC}_{50}\right)$ for penaeid shrimp were estimated in short-duration tests (acute toxicity tests) [e.g. Penaeus monodon (Fabricius, 1798); Marsupenaeus japonicus (Bate, 1888); Fenneropenaeus indicus (H. Milne-Edwards, 1837); Farfantepenaeus chinensis (Osbeck, 1765); Litopenaeus vannamei (Boone, 1931); Litopenaeus schmitti (Burkenroad, 1936); F. paulensis, etc)]. Miranda-Filho and Costa (2015) have also published

Table 1. Nominal concentrations of ammonia $(\mathrm{mg} / \mathrm{L} \mathrm{TA}-\mathrm{N})$, nitrite $\left(\mathrm{mg} / \mathrm{L} \mathrm{NO}_{2}^{-}-\mathrm{N}\right)$ and nitrate $\left(\mathrm{mg} / \mathrm{L} \mathrm{NO}_{3}^{-}-\mathrm{N}\right)$ used in the experiments.

\begin{tabular}{lccc}
\hline \multirow{2}{*}{ Toxic Compounds } & \multicolumn{3}{c}{ Treatments } \\
\cline { 2 - 4 } & A & B & C \\
\hline Ammonia & 0.91 & 3.65 & 7.30 \\
Nitrite & 2.55 & 10.2 & 20.4 \\
Nitrate & 80.7 & 323 & 646 \\
\hline
\end{tabular}

\begin{tabular}{lcccc}
\hline \multirow{2}{*}{ Test } & \multirow{2}{*}{ Treatments } & \multicolumn{3}{c}{ Physicochemical parameter } \\
\cline { 3 - 5 } & & Temperature & pH & Dissolved Oxygen \\
\hline Control & & $25.1 \pm 0.9$ & $8.13 \pm 0.21$ & $7.53 \pm 1.4$ \\
\hline Ammonia & A & $25.0 \pm 0.7$ & $8.01 \pm 0.26$ & $7.19 \pm 2.1$ \\
& B & $25.2 \pm 0.8$ & $8.12 \pm 0.24$ & $7.55 \pm 1.5$ \\
& C & $25.0 \pm 0.8$ & $8.10 \pm 0.28$ & $7.51 \pm 1.7$ \\
\hline Nitrite & A & $25.8 \pm 1.1$ & $8.12 \pm 0.34$ & $7.25 \pm 1.3$ \\
& B & $25.5 \pm 0.7$ & $8.16 \pm 0.21$ & $6.88 \pm 1.6$ \\
& C & $25.4 \pm 0.7$ & $8.12 \pm 0.17$ & $7.15 \pm 1.6$ \\
\hline Nitrate & A & $25.3 \pm 0.6$ & $8.08 \pm 0.24$ & $7.10 \pm 1.9$ \\
& B & $25.2 \pm 0.9$ & $8.06 \pm 0.21$ & $6.89 \pm 2.0$ \\
& C & $25.9 \pm 0.9$ & $8.11 \pm 0.10$ & $7.30 \pm 1.5$ \\
\hline
\end{tabular}

Treatment (A) a quarter of safety level; treatment (B) safety level; treatment (C) twice the safety level. Temperature $\left({ }^{\circ} \mathrm{C}\right), \mathrm{pH}$ and mean concentration of dissolved oxygen $(\mathrm{mg} / \mathrm{L})$ in different treatments in 30-day trials with nitrogenous compounds using Farfantepenaeus paulensis juveniles. Data are mean \pm SD. 
Table 2. Survival (number of animals and percentual), final weight $(\mathrm{mg})$ and biomass $(\mathrm{g})$ of shrimp Farfantepenaeus paulensis exposed to different concentrations of ammonia $\left(\mathrm{mg} / \mathrm{L} \mathrm{TA}-\mathrm{N} / \mathrm{NH}_{3}-\mathrm{N}\right)$. Data are based on three replicates $(\mathrm{mean} \pm \mathrm{SD})$.

\begin{tabular}{ccccc}
\hline Treatment & Survival & Survival (\%) & Final weight & Final biomass \\
\hline Control & $26.7^{\mathrm{A}}$ & $88.9^{\mathrm{A}}$ & $431^{\mathrm{A}}$ & $11.49^{\mathrm{A}}$ \\
& $(26.1-27.3)$ & & $(409-453)$ & $(10.81-12.18)$ \\
$\mathrm{T}_{1 / 4} 0.91 / 0.0453$ & $28.0^{\mathrm{A}}$ & $93.3^{\mathrm{A}}$ & $340^{\mathrm{B}}$ & $9.52^{\mathrm{B}}$ \\
& $(27.0-29.0)$ & & $(304-376)$ & $(8.65-10.40)$ \\
$\mathrm{T}_{\mathrm{SL}} 3.65 / 0.2363$ & $27.7^{\mathrm{A}}$ & $92.2^{\mathrm{A}}$ & $260^{\mathrm{B}}$ & $7.18^{\mathrm{C}}$ \\
& $(26.1-29.3)$ & & $(233-287)$ & $(6.79-7.58)$ \\
$\mathrm{T}_{2 \mathrm{X}} 7.30 / 0.4453$ & $15.7^{\mathrm{B}}$ & $52.2^{\mathrm{B}}$ & $265^{\mathrm{B}}$ & $4.15^{\mathrm{D}}$ \\
& $(15.1-16.3)$ & & $(228-302)$ & $(3.53-4.77)$ \\
\hline
\end{tabular}

Identical letters in columns indicate statistically equal means $(\mathrm{P}>0.05)$.

Table 3. Survival (number of animals and percentual), final weight ( $\mathrm{mg}$ ) and biomass ( $\mathrm{g}$ ) of shrimp Farfantepenaeus paulensis exposed to different concentrations of nitrite $\left(\mathrm{mg} / \mathrm{L} \mathrm{NO}_{2}^{-}-\mathrm{N}\right)$. Data are based on three replicates $(\mathrm{mean} \pm \mathrm{SD})$.

\begin{tabular}{lcccc}
\hline \multicolumn{1}{c}{ Treatments } & Survival & Survival $(\%)$ & Final weight & Final biomass \\
\hline Control & $26.7^{\mathrm{A}}$ & $88.9^{\mathrm{A}}$ & $431^{\mathrm{A}}$ & $11.49^{\mathrm{A}}$ \\
& $(26.1-27.3)$ & & $(409-453)$ & $(10.81-12.18)$ \\
$\mathrm{T}_{1 / 4}(2.55 \mathrm{mg} / \mathrm{L})$ & $27.3^{\mathrm{A}}$ & $91.0^{\mathrm{A}}$ & $438^{\mathrm{A}}$ & $11.93^{\mathrm{A}}$ \\
& $(25.2-29.4)$ & & $(408-468)$ & $(11.73-12.13)$ \\
$\mathrm{T}_{\mathrm{SL}}(10.2 \mathrm{mg} / \mathrm{L})$ & $11.7^{\mathrm{B}}$ & $39.0^{\mathrm{B}}$ & $381^{\mathrm{A}}$ & $4.45^{\mathrm{B}}$ \\
& $(10.17-13.23)$ & & $(373-389)$ & $(3.83-5.07)$ \\
$\mathrm{T}_{2 \mathrm{X}}(20.4 \mathrm{mg} / \mathrm{L})$ & $4.7^{\mathrm{C}}$ & $15.7^{\mathrm{C}}$ & $311^{\mathrm{B}}$ & $1.46^{\mathrm{C}}$ \\
& $(3.55-5.85)$ & & $(288-334)$ & $(1.07-1.84)$ \\
\hline
\end{tabular}

Identical letters in columns indicate statistically equal treatment means $(\mathrm{P}>0.05)$.

Table 4. Survival (number of animals and percentual), weight (mg) and biomass (g) of juvenile pink shrimp Farfantepenaeus paulensis exposed to different concentrations of nitrate $\left(\mathrm{mg} / \mathrm{L} \mathrm{NO}_{3}^{-}-\mathrm{N}\right)$. Data are based on three replicates $(\mathrm{mean} \pm \mathrm{SD})$.

\begin{tabular}{lcccc}
\hline Treatments & Survival & \% Survival & Final weight & Final biomass \\
\hline Control & $26.7^{\mathrm{A}}$ & $88.9^{\mathrm{A}}$ & $431^{\mathrm{A}}$ & $11.49^{\mathrm{A}}$ \\
& $(26.10-27.30)$ & & $(409-453)$ & $(10.81-12.18)$ \\
$\mathrm{T}_{1 / 4}(80.7 \mathrm{mg} / \mathrm{L})$ & $21.7^{\mathrm{A}}$ & $72.2^{\mathrm{A}}$ & $323^{\mathrm{B}}$ & $7.00^{\mathrm{B}}$ \\
& $(21.10-22.30)$ & & $(304-341)$ & $(6.44-7.57)$ \\
$\mathrm{T}_{\mathrm{SL}}(323 \mathrm{mg} / \mathrm{L})$ & $21.0^{\mathrm{A}}$ & $70.2^{\mathrm{A}}$ & $259^{\mathrm{B}}$ & $5.45^{\mathrm{B}}$ \\
& $(17.00-25.00)$ & & $(253-265)$ & $(4.36-6.53)$ \\
$\mathrm{T}_{2 \mathrm{X}}(646 \mathrm{mg} / \mathrm{L})$ & $12.07^{\mathrm{B}}$ & $40.0^{\mathrm{B}}$ & $275^{\mathrm{B}}$ & $3.26^{\mathrm{C}}$ \\
& $(10.07-14.07)$ & & $(212-338)$ & $(2.61-3.90)$ \\
\hline
\end{tabular}

Identical letters in columns indicate statistically equal treatment means $(\mathrm{P}>0.05)$.

a compilation of $\mathrm{LC}_{50}$ for fish and crustaceans. However, Tomasso (1994) states that the actual safety levels for different species can often vary quite substantially from the values obtained from short-duration tests.

In the present study, chronic concentrations of nitrogenous compounds tested were based on safety levels. However, according to the results, this approach may be misleading and can undermine aquaculture activities. For example, the survival of shrimp at the security level $\left(\mathrm{T}_{\mathrm{SL}}\right)$ after 30 days of ammonia exposure showed no differences compared with the control condition. However, the results in wet weight and final biomass showed that even a concentration as low as $0.91 \mathrm{mg} / \mathrm{L} \mathrm{TA}-\mathrm{N}$ (total ammonia as nitrogen), corresponding to $1 / 4$ of the security level (Ostrensky and Wasielesky, 1995), caused a decrease in the growth rate. The results for the nitrite treatments showed that the weight gain, corresponding to the safety level concentration (Castaño, 1997) $\left(\mathrm{T}_{\mathrm{SL}}\right)$, did not differ statistically from that observed in the control treatment. However, the survival of $F$. paulensis was significantly affected. Moreover, as observed for ammonia, the survival of the shrimps exposed to nitrate at the safety level concentration (Sachisida, 1997) was similar to that found in the control. However, the growth in weight and final biomass were reduced by nitrate exposure.

In this context, the weight gain of penaeid shrimp has provided a practical method to allow researchers to define sublethal effects caused by nitrogenous compounds in these organisms. Thus, Chen and Kou (1992), working with juvenile M. japonicus, found that after 60 days, this species showed growth reductions between 12.8 and $36.6 \%$ in ammonia concentrations ranging between 5 and $30 \mathrm{mg} / \mathrm{L}$ TA-N 
( 0.35 and $2.1 \mathrm{mg} / \mathrm{L} \mathrm{NH}_{3}-\mathrm{N}$ ), respectively. These authors found that juvenile M. japonicus exposed to 0, 5, 10, 20 and $30 \mathrm{mg} / \mathrm{L} \mathrm{TA}-\mathrm{N}\left(0,0.35,0.70,1.40\right.$ and $\left.2.10 \mathrm{mg} / \mathrm{L} \mathrm{NH}_{3}-\mathrm{N}\right)$ had reduced intermolt periods estimated as 21.9, 19.2, 17.7, 14.6 and 10.3 days, respectively. However, these findings did not represent an increase in growth rate. They occurred in response to the stressful experimental treatments. Chen and Lin (1992a) found a decrease in growth in juvenile $P$. monodon at 4,8 and $20 \mathrm{mg} / \mathrm{L} \mathrm{TA-N}$ after 30 days of exposure. These authors, working with juvenile Farfantepenaeus penicillatus (Alcock, 1905), estimated that the concentration that reduced the growth rate to $50 \%$ of that in the control group (at 56 days) was $12.65 \mathrm{mg} / \mathrm{L}$ TA-N (Chen and Lin, 1992b). In the present study, F. paulensis juveniles showed a reduction in weight growth of 21.1, 39.7 and 38.5\% compared with the control at concentrations of $0.91,3.65$ and $7.30 \mathrm{mg} / \mathrm{L}$ TA-N, respectively. These results indicate that $F$. paulensis is more susceptible to ammonia than the other species cited.

Laboratory studies have shown different chronic effects of ammonia in F. paulensis according to age, sex, stage of maturation and methodology of research applied. For example, Cavalli et al. (1998) analyzed the effect of ammonia on adults of $F$. paulensis reporting lower growth rates in females in the treatment containing $6.86 \mathrm{mg} / \mathrm{L}$ TA-N. However, this effect was not observed in males. In post-larvae of $F$. paulensis, Wasielesky et al. (1994) confirmed significant reductions in the growth rates of the shrimp at concentrations of 2,3 and $4 \mathrm{mg} / \mathrm{L}$ TA-N $(0.07$, 0.11 and $0.14 \mathrm{mg} / \mathrm{L} \mathrm{NH}_{3}-\mathrm{N}$ ). Miranda-Filho et al. (2009) found that juvenile $F$. paulensis showed reduced growth at concentrations of $1.86,3.32,6.27$ and $13.3 \mathrm{mg} / \mathrm{L} \mathrm{TA}-\mathrm{N}$ $\left(0.05,0.1,0.2\right.$ and $\left.0.4 \mathrm{mg} / \mathrm{L} \mathrm{NH}_{3}-\mathrm{N}\right)$, at the end of a 75 -day experiment.

Wickins (1976) working with Penaeus semisulcatus (De Haan, 1844), M. japonicus, Litopenaeus occidentalis (Streets, 1871), Litopenaeus setiferus (Linnaeus, 1767) and $L$. schmitti has indicated that the maximum acceptable level in cropping systems for penaeids would be $0.1 \mathrm{mg} / \mathrm{L}$ $\mathrm{NH}_{3}-\mathrm{N}$. However, the results obtained in the present study, combined with others cited above, indicate that the maximum acceptable level of ammonia proposed by Wickins (1976) is not suitable for F. paulensis because chronic effects on the growth of shrimp species have been found at concentrations below that level.

Studies of the chronic effects of nitrite on penaeid shrimp are scarce. In addition, most previous studies examine effects of nitrite on growth or sublethal concentrations determined from short-term tests. For example, Chen and Cheng (1996) and Cheng and Chen (1998) observed changes in acid-base balance, ammonia excretion and osmoregulation; and increase of hemolymph urea and decrease of arginine, respectively, in M. japonicus exposed to nitrite concentrations between 0.03 and $0.065 \mathrm{mg} / \mathrm{L}$. Chen et al. (1990) estimated a safety level of $10.6 \mathrm{mg} / \mathrm{L} \mathrm{NO}_{2}{ }^{-}-\mathrm{N}$ for juvenile $P$. monodon. Working with adults and juveniles of $F$. paulensis, Cavalli et al. (1996) and Ostrensky (1997) estimated safety levels of 10.94 and $10.2 \mathrm{mg} / \mathrm{L} \mathrm{NO}_{2}{ }^{-} \mathrm{N}$, respectively. These results were similar to those obtained by Chen et al. (1990) with juveniles of $P$. monodon.

In order to investigate the chronic effects of nitrite, Chen and Chen (1992) exposed juvenile P. monodon to concentrations ranging between 2 and $20 \mathrm{mg} / \mathrm{L} \mathrm{NO}_{2}-\mathrm{N}$ for 60 days. In the shrimp subjected to 4,8 and $20 \mathrm{mg} / \mathrm{L}$ $\mathrm{NO}_{2}^{-}-\mathrm{N}$, the body weight gain was significantly lower. These authors estimated the median effective concentration $\left(\mathrm{EC}_{50}\right)$ (60 days) for P. monodon as $17.4 \mathrm{mg} / \mathrm{L} \mathrm{NO}_{2}{ }^{-} \mathrm{N}$. In turn, Armstrong et al. (1976) found a 35\% growth reduction of Macrobrachium rosenbergii (De Man, 1879) prawn exposed to a concentration of $1.8 \mathrm{mg} / \mathrm{L} \mathrm{NO}_{2}^{-}-\mathrm{N}$ for 30 days. Wickins (1976) concluded that chronic exposure to $6.2 \mathrm{mg} / \mathrm{L} \mathrm{NO}_{2}{ }^{-}-\mathrm{N}$ can cause a decrease of $50 \%$ in the shrimp growth. The current study found that juvenile F. paulensis only showed a significant decrease in weight at a concentration of $20.4 \mathrm{mg} / \mathrm{L} \mathrm{NO}_{2}^{-}-\mathrm{N}$ (twice the safety level) after 30 days of testing. Moreover, F. paulensis showed a mortality of $61 \%$ at a concentration of $10.2 \mathrm{mg} / \mathrm{L} \mathrm{NO}_{2}^{-}-\mathrm{N}$, while $P$. monodon, even if exposed for a longer period than F. paulensis, showed high survival up to a concentration of $8 \mathrm{mg} / \mathrm{L} \mathrm{NO}_{2}^{-}-\mathrm{N}$ (Chen and Chen, 1992). In contrast, despite the high mortality rate of juvenile $F$. paulensis at a concentration of $10.2 \mathrm{mg} / \mathrm{L} \mathrm{NO}_{2}-\mathrm{N}$, the growth of the shrimps that survived was not affected by nitrite. It is probable that this result is related to the increased need for oxygen during the molting process. The presence of nitrite is harmful during molting because it interferes with oxygen uptake. As previously mentioned, nitrite transforms hemocyanin into meta-hemocyanin, decreasing the delivery of oxygen to the tissues. It is suggested that the shrimp during molting stage (ecdysis) shows a relatively normal weight gain for a period of 30 days, as seen at the concentration of $10.2 \mathrm{mg} / \mathrm{L} \mathrm{NO}_{2}^{-}-\mathrm{N}$.

Nitrate is considered a weak toxicant to crustaceans and in high concentrations in the water, nitrate can accumulate in the shrimp tissue (Cheng et al., 2002). Colt and Armstrong (1981) stated that the lethal levels for short-term exposure varied between 1,000 and 3,000 $\mathrm{mg} / \mathrm{L} \mathrm{NO}_{3}^{-}-\mathrm{N}$. Wickins (1976) estimated that concentrations of up to $200 \mathrm{mg} / \mathrm{L} \mathrm{NO}_{3}^{-}-\mathrm{N}$ would not affect the growth of penaeid shrimp. Moreover, Colt and Armstrong (1981) stated that the growth of the shrimp M. rosenbergii decreased by 50\% at a concentration of $180 \mathrm{mg} / \mathrm{L} \mathrm{NO}_{3}^{-}-\mathrm{N}$ and Spotte (1979) reported that approximately $20 \mathrm{mg} / \mathrm{L} \mathrm{NO}_{3}-\mathrm{N}$ would be the acceptable level of nitrate for seawater culture. Kuhn et al. (2010) demonstrated that $200 \mathrm{mg} / \mathrm{L} \mathrm{NO}_{3}^{-}-\mathrm{N}$ at salinity $11 \mathrm{ppt}$ would be safe to juveniles $L$. vannamei. However, in the current study, juvenile $F$. paulensis exposed to $80.7 \mathrm{mg} / \mathrm{L} \mathrm{NO}_{3}-\mathrm{N}$, presented lower growth rates compared to control indicating that this species is more sensitive to nitrate than other crustaceans.

Ammonia, nitrite and nitrate are substances that generally do not reach high concentrations in the natural environment. Nevertheless, in high density aquaculture systems, nitrogenous compounds can reach high levels. Chen et al. (1988) reported that concentrations of $46.11 \mathrm{mg} / \mathrm{L}$ TA-N $(0.84$ $\left.\mathrm{mg} / \mathrm{L} \mathrm{NH}_{3}-\mathrm{N}\right), 0.83 \mathrm{mg} / \mathrm{L} \mathrm{NO}_{2}{ }^{-}-\mathrm{N}$ and $1,795 \mathrm{mg} / \mathrm{L} \mathrm{NO}_{3}^{-}-\mathrm{N}$ 
were reached in superintensive cultures of $F$. penicillatus. Yont et al. (1996) found $0.86 \mathrm{mg} / \mathrm{L} \mathrm{NH}_{3}-\mathrm{N}$ in an intensive culture of P. monodon. Furthermore, Chen and Wang (1990) measured concentrations between 0.01 and $2.0 \mathrm{mg} / \mathrm{L} \mathrm{NO}_{2}-\mathrm{N}$ in cultures of $P$. monodon and $F$. penicillatus. In addition, Muir et al. (1991) reported the frequent occurrence of concentrations between 10 and $20 \mathrm{mg} / \mathrm{L} \mathrm{NO}_{3}^{-}-\mathrm{N}$ in penaeid culture. In this study, chronic effects on the survival and/or growth of the shrimp F. paulensis occurred from exposure to ammonia and nitrate concentrations equivalent to $1 / 4$ of the safety levels for this species. Moreover, nitrite was toxic at concentrations equivalent to the proposed level of security.

According to what has been described, particular caution must be taken to control the concentrations of nitrogenous compounds during shrimp production in captivity. These findings confirm that experiments involving long-term exposures are needed to produce valid estimates, as previously suggested by Tomasso (1994).

\section{Conclusion}

The present study showed that the safety level as proposed by Sprague (1971), based on acute-toxicity tests, must be tested in order to prove if the concentrations are really safe. For pink shrimp F. paulensis, the proposed level of security for nitrite was $2.55 \mathrm{mg} / \mathrm{L} \mathrm{NO}_{2}-\mathrm{N}$. The safety levels for ammonia and nitrate were not determined and concentrations of less than $0.91 \mathrm{mg} / \mathrm{L} \mathrm{TA}-\mathrm{N}$ (corresponding to $0.045 \mathrm{mg} / \mathrm{L} \mathrm{NH}_{3}-\mathrm{N}$ ) and $80.7 \mathrm{mg} / \mathrm{L} \mathrm{NO}_{3}^{-}-\mathrm{N}$, respectively, are recommended for the production of $F$. paulensis.

\section{Acknowledgements}

Wilson Wasielesky Junior, Luis Henrique Poersch and Kleber C. Miranda Filho are research fellows of CNPq.

\section{References}

ABREU, P.C., BALleSTER, E.L.C., ODEBRECHT, C., WASIELESKY, W.J., CAVALLI, R.O., GRANÉLI, W. and ANESIO, A.M., 2007. Importance of biofilm as food source for shrimp (Farfantepenaeus paulensis) evaluated by stable isotopes $(\delta 13 \mathrm{C}$ and $\delta 15 \mathrm{~N})$. Journal of Experimental Marine Biology and Ecology, vol. 347, no. 1-2, pp. 88-96. http://dx.doi.org/10.1016/j. jembe.2007.03.012.

ARMSTRONG, D.A., STEPHENSON, M.J. and KNIGHT, A.W., 1976. Acute toxicity of nitrite to larvae of giant Malasyan prawn, Macrobrachium rosenbergii. Aquaculture (Amsterdam, Netherlands), vol. 9, pp. 39-46. http://dx.doi.org/10.1016/00448486(76)90046-6.

BALDISSEROTTO, B., 2009. Fisiologia de peixes aplicada à aquicultura. 2. ed. Santa Maria: Editora UFSM.

BALlester, E.L.C., ABREU, P.C., CAVAlLI, R.O., EMERENCIANO, M., DE ABREU, L. and WASIELESKY, W.J., 2010. Effect of practical diets with different protein levels on the performance of Farfantepenaeus paulensis juveniles nursed in a zero Exchange suspended microbial flocs intensive system.
Aquaculture Nutrition, vol. 16, no. 2, pp. 163-172. http://dx.doi. org/10.1111/j.1365-2095.2009.00648.x.

BALLESTER, E.L.C., WASIELESKY, W.J., CAVALLI, R.O. and ABREU, P.C., 2007. Nursery of the pink shrimp Farfantepenaeus paulensis in cages with artificial substrates: Biofilm composition and shrimp performance. Aquaculture (Amsterdam, Netherlands), vol. 269 , no. $1-4$, pp. 355-362. http://dx.doi.org/10.1016/j. aquaculture.2007.04.003.

BARBIERI, E., 2010. Acute toxicity of ammonia in white shrimp (Litopenaeus schmitti) (Burkenroad, 1936, Crustacea) at different salinity levels. Aquaculture (Amsterdam, Netherlands), vol. 306, no. 1-4, pp. 329-333. http://dx.doi.org/10.1016/j. aquaculture.2010.06.009.

BOWER, C.E. and BIDWELL, J., 1978. Ionization of ammonia in the sea water: Effects of temperature, $\mathrm{pH}$ and salinity. Journal of the Fisheries Research Board of Canada, vol. 35, no. 7, pp. 1012-1016. http://dx.doi.org/10.1139/f78-165.

CASTAÑO, C.S., 1997. Acute toxicity of nitrite on pink-shrimp Penaeus paulensis, cultured in different salinities [In Portuguese, English summary]. Rio Grande: Universidade Federal do Rio Grande. Undergraduate Monograph in Oceanology.

CAVALLI, R.O., PEIXOTO, S.M. and WASIELESKY, W.J., 1998. Performance of Penaeus paulensis (Pérez-Farfante) broodstock under long-term exposure to ammonia. Aquaculture Research, vol. 29, no. 11, pp. 815-822. http://dx.doi.org/10.1111/j.1365-2109.1998. tb01107.x.

CAVALLI, R.O., WASIELESKY, W.J., FRANCO, C.S. and MIRANDA-FILHO, K.C., 1996. Evaluation of the short-term toxicity of ammonia, nitrite and nitrate to Penaeus paulensis (Crustacea, Decapoda) broodstock. Brazilian Arquives of Biology and Technology, vol. 39, no. 3, pp. 567-575.

CHEN, J.C. and CHEN, S.F., 1992. Effects of nitrite on growth and molting of Penaeus monodon juveniles. Comparative Biochemistry and Physiology C, vol. 101, no. 3, pp. 453-458. http://dx.doi.org/10.1016/0742-8413(92)90069-J.

CHEN, J.C. and CHENG, S.Y., 1996. Hemolymph osmolality, acid-base balance, and ammonia excretion of Penaeus japonicus Bate exposed to ambient nitrite. Archives of Environmental Contamination and Toxicology, vol. 30, no. 2, pp. 151-155. http:// dx.doi.org/10.1007/BF00215792.

CHEN, J.C. and CHIN, T.S., 1988. Acute toxicity of nitrite to tiger prawn, Penaeus monodon, larvae. Aquaculture (Amsterdam, Netherlands), vol. 69, no. 3-4, pp. 253-262. http://dx.doi. org/10.1016/0044-8486(88)90333-X

CHEN, J.C. and KOU, Y.Z., 1992. Effects of ammonia on growth and molting of Penaeus japonicus juveniles. Aquaculture (Amsterdam, Netherlands), vol. 104, no. 3-4, pp. 249-260. http:// dx.doi.org/10.1016/0044-8486(92)90207-2.

CHEN, J.C. and LIN, C.Y., 1992a. Effects of ammonia on growth and molting of Penaeus monodon juveniles. Comparative Biochemistry and Physiology C, vol. 101, no. 3, pp. 449-452. http://dx.doi.org/10.1016/0742-8413(92)90068-I.

CHEN, J.C. and LIN, C.Y., 1992b. Effects of ammonia on growth of Penaeus penicillatus juveniles. Comparative Biochemistry and Physiology C, vol. 101, no. 3, pp. 443-447. http://dx.doi. org/10.1016/0742-8413(92)90067-H.

CHEN, J.C. and WANG, T.C., 1990. Culture of tiger shrimp and red tailed shrimp in a semi static system. In: Proceedings of the 
Second Asian Fisheries Forum, 17-22 April 1989, Tokyo, Japan. Selangor: Asian Fisheries Society, pp. 77-80.

CHEN, J.C., CHIN, C.K. and LEE, C.K., 1986. Effects of ammonia and nitrite on larval development of the shrimp Penaeus monodon. In: Proceedings of the First Asian Fisheries Forum, 26-31 May 1986, Manila, Philippines. Selangor: Asian Fisheries Society, pp. 657-662.

CHEN, J.C., LIU, P.C. and LEI, S.C., 1990. Toxicities of ammonia and nitrite to Penaeus monodon adolescents. Aquaculture (Amsterdam, Netherlands), vol. 89, no. 2, pp. 127-137. http:// dx.doi.org/10.1016/0044-8486(90)90305-7.

CHEN, J.C., LIU, P.C., LIN, Y.T. and LEE, C.K., 1988. Super intensive culture of red-tailed shrimp Penaeus penicillatus. Journal of the World Aquaculture Society, vol. 19, no. 3, pp. 127-131. http://dx.doi.org/10.1111/j.1749-7345.1988.tb00940.x.

CHENG, S.Y. and CHEN, J.C., 1998. Effects of nitrite exposure on the hemolymph electrolyte, respiratory protein and free amino acid levels and water content of Penaeus japonicus. Aquatic Toxicology, vol. 44, no. 1-2, pp. 129-139.

CHENG, S.Y., TSAI, S.J. and CHEN, J.C., 2002. Accumulation of nitrate in the tissues of Penaeus monodon following elevated ambient nitrate exposure after different time periods. Aquatic Toxicology, vol. 56, pp. 133-146.

COLT, J.E. and ARMSTRONG, D.A., 1981. Nitrogen toxicity to crustaceans, fish and molluscs. In: L.J. ALLEN and E. C. KINNEY, eds. Proceedings of the Bioengeneering Symposium for Fish Culture Section. Bethesda: Americam Fisheries Society, pp. 34-47.

EMERENCIANO, M.G.C., WASIELESKY, W.J., SOARES, R.B., BALLESTER, E.C., IZEPPI, E.M. and CAVALLI, R.O., 2007. Crescimento e sobrevivência do camarão-rosa (Farfantepenaeus paulensis) na fase de berçário em meio heterotrófico. Acta Scientiarum, vol. 29, no. 1, pp. 1-7.

HENRIQUES, M.B., ALVES, P.M.F., BARRETO, O.J.S. and SOUZA, M.R., 2014. Growth of Litopenaeus schmitti (Burkenroad, 1936) and Farfantepenaeus paulensis (Perez-Farfante, 1967) shrimp reared in recirculation culture system. Brazilian Journal of Oceanography, vol. 62, no. 4, pp. 323-330. http://dx.doi. org/10.1590/S1679-87592014078806204.

INNOCENTI, A., ZIMMERMAN, S., FERRY, J.G., SCOZZAFAVA, A. and SUPURAN, C.T., 2004. Carbonic anhydrase inhibitors. Inhibition of the zinc and cobalt $\gamma$-class enzyme from the archaeon Methanosarcina thermophila with anions. Bioorganic \& Medicinal Chemistry Letters, vol. 14, no. 12, pp. 3327-3331. PMid:15149700.

KIR, M. and KUMLU, M., 2006. Acute toxicity of ammonia to Penaeus semisulcatus postlarvae in relation to salinity. Journal of the World Aquaculture Society, vol. 37, no. 2, pp. 231-235. http://dx.doi.org/10.1111/j.1749-7345.2006.00033.x.

KUHN, D.D., SMITH, S.A., BOARDMAN, G.D., ANGIER, M.W., MARSH, L. and FLICK-JUNIOR, G.J., 2010. Chronic toxicity of nitrate to Pacific white shrimp, Litopenaeus vannamei: Impacts on survival, growth, antennae length, and pathology. Aquaculture (Amsterdam, Netherlands), vol. 309, no. 1-4, pp. 109-114. http://dx.doi.org/10.1016/j.aquaculture.2010.09.014.

LAZZARI, R. and BALDISSEROTTO, B., 2008. Nitrogen and phosphorus waste in fish farming. Boletim do Instituto de Pesca, vol. 34 , no. 4 , pp. 591-600.

LIN, Y.C. and CHEN, J.C., 2001. Acute toxicity of ammonia on Litopenaeus vannamei (Boone) juveniles at different salinity levels. Journal of Experimental Marine Biology and Ecology, vol. 259, no. 1, pp. 109-119. PMid:11325379. http://dx.doi.org/10.1016/ S0022-0981(01)00227-1.

LIN, Y.C. and CHEN, J.C., 2003. Acute toxicity of nitrite on Litopenaeus vannamei (Boone) juveniles at different salinity levels. Aquaculture (Amsterdam, Netherlands), vol. 224, no. 1-4, pp. 193-201. http://dx.doi.org/10.1016/S0044-8486(03)00220-5.

LUO, G.-Z., AVNIMELECH, Y., PAN, W.-F. and TAN, H.-X., 2013. Inorganic nitrogen dynamics in sequencing batch reactors using biofloc technology to treat aquaculture sludge. Aquacultural Engineering, vol. 52, pp. 73-79. http://dx.doi.org/10.1016/j. aquaeng.2012.09.003.

MIRANDA-FILHO, K.C. and COSTA, L.D.F., 2015. Deleterious effects of ammonia and nitrite to fish and crustaceans, chapter 26. In: M. TAVARES $\square$ DIAS and W.S. MARIANO, orgs. Aquicultura no Brasil: novas perspectivas. São Carlos: Pedro \& João Editores, vol. 2, pp. 545-578.

MIRANDA-FILHO, K.C., PINHO, G.L.L., WASIELESKY, W.J. Jr. and BIANCHINI, A., 2009. Long-term ammonia toxicity to the pink-shrimp Farfantepenaeus paulensis. Comparative Biochemistry and Physiology C, vol. 150, no. 3, pp. 377-382. PMid:19524063.

MUIR, P.R., SUTTON, D.C. and OWENS, L., 1991. Nitrate toxicity to Penaeus monodon protozoea. Marine Biology, vol. 108, no. 1, pp. 67-71. http://dx.doi.org/10.1007/BF01313472.

OSTRENSKY, A. and WASIELESKY, W.J., 1995. Acute toxicity of ammonia to various life stages of the São Paulo shrimp Penaeus paulensis Pérez-Farfante, 1967. Aquaculture (Amsterdam, Netherlands), vol. 132, no. 3-4, pp. 339-347. http:// dx.doi.org/10.1016/0044-8486(94)00343-M.

OSTRENSKY, A., 1997. Studies on technological viability of marine shrimp culture in Paraná state, Brazil [In Portuguese, English summary]. Curitiba: Universidade Federal do Paraná. $\mathrm{PhD}$ Thesis in Zoology.

OSTRENSKY, A., MARCHIORI, M.A. and POERSCH, L.H., 1992. Toxicidade aguda da amônia no processo produtivo de pós-larvas de Penaeus paulensis Pérez-Farfante, 1967. Anais da Academia Brasileira de Ciências, vol. 64, no. 4, pp. 383-389. PMid:1295382.

PEIXOTO, S. Jr., WASIELESKY, W.J. Jr. and LOUZADA, L.J. Jr., 2003. Comparative analysis of pink shrimp, Farfantepenaeus paulensis, and Pacific white shrimp, Litopenaeus vannamei, culture in extreme southern Brazil. Journal of Applied Aquaculture, vol. 14, no. 1-2, pp.101-111. http://dx.doi.org/10.1300/J028v14n01_07.

PEIXOTO, S., 1996. Effect of ammonia on reproductive performance of pink-shrimp Penaeus paulensis captured in the Patos Lagoon estuary [In Portuguese, English summary]. Rio Grande: Universidade Federal do Rio Grande. Undergraduate Monograph in Oceanology.

PEIXOTO, S., CAVALLI, R.O., WASIELESKY, W.J., D'INCAO, F., KRUMMENAUER, D. and MILACH, A.M., 2004. Effects of age and size on reproductive performance of captive Farfantepenaeus paulensis broodstock. Aquaculture (Amsterdam, Netherlands), vol. 238, no. 1-4, pp. 173-182. http://dx.doi.org/10.1016/j. aquaculture.2004.04.024.

ROMANO, N. and ZENG, C., 2013. Toxic effects of ammonia, nitrite and nitrate to decapod crustaceans: a review on factors influencing their toxicity, physiological consequences, and coping mechanisms. Reviews in Fisheries Science, vol. 21, no. 1, pp. 1-21. http://dx.doi.org/10.1080/10641262.2012.753404. 
SACHISIDA, A., 1997. Effect of nitrate on growth of pink-shrimp juveniles Penaeus paulensis (Crustacea: Decapoda) [In Portuguese, English summary]. Rio Grande: Universidade Federal do Rio Grande. Undergraduate Monograph in Oceanology.

SPIECK, E. and BOCK, E., 2005. The lithoautotrophic nitriteoxidizing bacteria. In: D.J. BRENNER, N.R. KRIEG, J.T. STALEY and G.M. GARRITY, eds. Bergey's manual of systematic bacteriology: the proteobacteria. Baltimore: Springer. vol. 2.

SPOTTE, S., 1979. Fish and invertebrate culture: water management in closed systems. 2nd ed. New York: John Wiley \& Sons. 179 p.

SPRAGUE, J.B., 1971. Measurement of pollutant toxicity to fishIII. Sublethal effects and "safe" concentrations. Water Research, vol. 5, no. 6, pp. 245-266. http://dx.doi.org/10.1016/00431354(71)90171-0.

TAHON, J.P., VAN HOOF, D., VINCKIER, C., WITTERS, R., DE LEY, M. and LONTIE, R., 1988. The reaction of nitrite with the haemocyanin of Astacus leptodactylus. The Biochemical Journal, vol. 249, no. 3, pp. 891-896. PMid:2833232. http:// dx.doi.org/10.1042/bj2490891.

THURSTON, R.V., RUSSO, R.C. and SMITH, C.E., 1978. Acute toxicity of ammonia and nitrite to cutthroat trout fry. Transactions of the American Fisheries Society, vol. 107, no. 2, pp. 361-368. http://dx.doi.org/10.1577/1548-8659(1978)107<361:ATOAA $\mathrm{N}>2.0 . \mathrm{CO} ; 2$.

TOMASSO, J.R., 1994. Toxicicity of nitrogenous Wastes to Aquaculture Animals. Reviews in Fisheries Science, vol. 2, no. 4, pp. 291-314. http://dx.doi.org/10.1080/10641269409388560.

TSAI, S.-J. and CHEN, J.-C., 2002. Acute toxicity of nitrate on Penaeus monodon juveniles at different salinity levels. Aquaculture
(Amsterdam, Netherlands), vol. 213, no. 1-4, pp. 163-170. http:// dx.doi.org/10.1016/S0044-8486(02)00023-6.

TSUZUKI, M. and CAVALLI, R.O., 2000. The effects of temperature, age, and acclimation to salinity on the survival of Farfantepenaeus paulensis postlarvae. Journal of the World Aquaculture Society, vol. 31, no. 3, pp. 459-468.

WASIELESKY, W.J., BIANCHINI, A., SANCHEZ, C.C. and POERSCH, L.H., 2003. The effect of temperature, salinity and nitrogen products on food consumption of pink shrimp Farfantepenaeus paulensis. Brazilian Archives of Biology and Technology, vol. 46, no. 1, pp. 135-141. http://dx.doi.org/10.1590/ S1516-89132003000100019.

WASIELESKY, W.J., MARCHIORI, M.A. and SANTOS, M.H.S., 1994. Efeito da amônia no crescimento de pós-larvas do camarãorosa Penaeus paulensis (PÉREZ-FARFANTE, 1967) (Decapoda: Penaeidae). Nauplius, vol. 2, pp. 99-105.

WHITFIELD, M., 1974. The hydrolysis of ammonium ions in sea-water. A theoretical study. Journal of the Marine Biological Association, vol. 54, no. 3, pp. 565-580. http://dx.doi.org/10.1017/ S002531540002275X.

WICKINS, J.F., 1976. The tolerance of warm water prawns to recirculated water. Aquaculture (Amsterdam, Netherlands), vol. 9, pp. 19-37. http://dx.doi.org/10.1016/0044-8486(76)90045-4.

WRIGHT, P.A. and WOOD, C.M., 2012. Seven things fish know about ammonia and we don't. Respiratory Physiology \& Neurobiology, vol. 184, no. 3, pp. 231-240. PMid:22910326. http://dx.doi.org/10.1016/j.resp.2012.07.003.

YONT, M., WANNA, R. and SUKSRI, S., 1996. Effluents from intensive culture ponds of tiger prawn Penaeus monodon, Fabricius. Fisheries Research Bulletin, vol. 21, pp. 17-24. 